\title{
Evidence obtained through violating the right to freedom from torture and other cruel, inhuman or degrading treatment in South Africa
}

Jamil Ddamulira Mujuzi*

Associate Professor of Law, Faculty of Law, University of the Western Cape, South Africa

\begin{abstract}
Summary
Although South African courts have expressly held that any evidence obtained through torture is always inadmissible, the author is unaware of a decision from a South African court to the effect that evidence obtained through cruel, inhuman and degrading treatment is, like evidence obtained through torture, inadmissible in all circumstances. In this article, the author first deals with the issue of evidence obtained through torture and thereafter relies on the practice of international and regional human rights bodies, such as the Committee against Torture, the Human Rights Committee, the UN Special Rapporteur on Torture, the UN Special Rapporteur on the Independence of Judges and Lawyers, the European Court of Human Rights and the African Commission on Human and Peoples' Rights, and some of the sections of the South African Constitution, to argue that South Africa has an international obligation to exclude any evidence obtained through cruel, inhuman and degrading treatment. In support of this argument, the author relies on the jurisprudence of the South African Supreme Court of Appeal on the nature of the right to freedom from torture and argues that the same approach could be applied to the right to freedom from cruel, inhuman and degrading treatment.
\end{abstract}

Key words: evidence obtained; torture, cruel, inhuman; South Africa; admissibility; exclusionary rule

* LLB (Makerere), LLM (Pretoria), LLM (Free State), LLD (Western Cape); djmujuzi@gmail.com. I am grateful to the anonymous reviewers for their comments. The usual caveats apply. 


\section{Introduction}

Section $12(1)(d)$ of the Constitution of the Republic of South Africa ${ }^{1}$ provides that everyone has the right 'not to be tortured in any way'. Section 12(1)(e) provides that everyone has a right 'not to be treated or punished in a cruel, inhuman or degrading way'. The rights under sections 12(1)(d) and (e) are non-derogable under the South African Constitution. ${ }^{2}$ In $S$ v Mthembu, ${ }^{3}$ the South African Supreme Court of Appeal (SCA) observed that, as in the case of torture, which is absolutely prohibited under international human rights law, 'our Constitution follows suit and extends the non-derogation principle to include cruel, inhuman and degrading treatment ${ }^{\prime} .4$ South Africa is also a state party to regional and international human rights instruments that prohibit torture, cruel, inhuman or degrading treatment or punishment. ${ }^{5}$ South Africa recently enacted legislation criminalising torture - the Prevention and Combating of Torture of Persons Act. ${ }^{6}$ This legislation which aims at, inter alia, giving effect to South Africa's obligations under the Convention against Torture (CAT), is silent on the issue of evidence obtained through torture. ${ }^{7}$ Section 35(5) of the South African Constitution provides:

Evidence obtained in a manner that violates any right in the Bill of Rights must be excluded if the admission of that evidence would render the trial unfair or otherwise be detrimental to the administration of justice.

Section 35(5) allows a court to admit evidence obtained in violation of a right or rights in the Bill of Rights, provided that the admission of the evidence in question would not render the trial unfair or otherwise be detrimental to the administration of justice. There is a growing jurisprudence from South African courts on section 35(5) and it is beyond the ambit of this article to deal with that jurisprudence. This is so especially in light of the fact that this jurisprudence does not deal with South Africa's international obligation to exclude evidence obtained through cruel, inhuman and degrading treatment (CIDT). ${ }^{8}$ Although some of these authors discuss the issue of evidence obtained

Constitution of the Republic of South Africa, 1996.
See table of non-derogable rights in the Constitution.

2008 (2) SACR 407 (SCA).

Mthembu (n 3 above) para 31.

5 These include the African Charter on Human and Peoples' Rights (art 5); the International Covenant on Civil and Political Rights (art 7); and the Convention against Torture.

6 Prevention and Combating of Torture of Persons Act 13 of 2013.

7 For the process of how international law becomes part of South African case law, see Glenister v President of the Republic of South Africa \& Others 2011 (3) SA 347 (CC), 374-375. See also paras 179-202 (judgment by Moseneke and Cameron JJ).

8 PJ Schwikkard \& SE van der Merwe (eds) Principles of evidence (2008) 181-266; DT Zeffert \& AP Paizes The South African law of evidence (2009) 711-775; A Bellengére et al The law of evidence in South Africa: Basic principles (2013) 234245; I Currie \& I de Waal The Bill of Rights handbook (2013) 269-289 (the authors deal with the rights in sec 12 of the Constitution). 
through torture, the discussion is very brief and is devoid of reference to any international human rights instrument. ${ }^{9}$ South African courts have held that evidence obtained through torture is inadmissible. What is not clear is whether evidence obtained through CIDT is also inadmissible under all circumstances. The purpose of this article is to rely on the practice of the Committee against Torture (CAT Committee) to argue that, because of the fact that the circumstances that lead to torture are not different from those that lead to CIDT, courts are urged to hold that evidence obtained through CIDT is also inadmissible. The article first deals with the status of evidence obtained through torture to lay the ground for the argument that evidence obtained through CIDT should be inadmissible.

\title{
2 South Africa's international and regional obligation to exclude evidence obtained through torture
}

As mentioned earlier, South Africa is a state party to the CAT. Article $1(1)$ of the CAT defines torture to mean

\begin{abstract}
any act by which severe pain or suffering, whether physical or mental, is intentionally inflicted on a person for such purposes as obtaining from him or a third person information or a confession, punishing him for an act he or a third person has committed or is suspected of having committed, or intimidating or coercing him or a third person, or for any reason based on discrimination of any kind, when such pain or suffering is inflicted by or at the instigation of or with the consent or acquiescence of a public official or other person acting in an official capacity. It does not include pain or suffering arising only from, inherent in or incidental to lawful sanctions.
\end{abstract}

This definition was relied on by South African courts before the Prevention and Combating of Torture of Persons Act was enacted. ${ }^{10}$ Section 3 of this Act substantially reproduces the definition of torture under article 1(1) of the CAT. However, unlike the CAT, the Prevention and Combating of Torture of Persons Act does not prohibit the admission of evidence obtained through torture. Article 15 of the CAT provides:

Each state party shall ensure that any statement which is established to have been made as a result of torture shall not be invoked as evidence in any proceedings, except against a person accused of torture as evidence that the statement was made.

It is clear that article 15 prohibits the admission of 'any statement' which has been made as a result of torture. There are three important points to note about article 15. One, it does not oblige South Africa to exclude a statement made as a result of CIDT. It is expressly limited to

9 Bellengére et al (n 8 above) 235; Schwikkard \& Van der Merwe (n 8 above) 218; Zeffert \& Paizes (n 8 above) 738740747749752 . In all cases, the discussion is limited to the SCA judgment in Mthembu ( $\mathrm{n} 3$ above).

10 See Mthembu (n 3 above) para 30; Kutumela $v$ Minister of Safety and Security [2008] ZAGPHC 430 (12 December 2008) para 86. 
torture. This is attributable to the drafting history of article 15 . Attempts by some countries to include CIDT under article 15 were unsuccessful. ${ }^{11}$ A strict interpretation of article 15, therefore, means that South Africa does not have an obligation to exclude statements made as a result of CIDT. In referring to article 15 of the CAT, the Supreme Court of Appeal held in Mthembu: ${ }^{12}$

In regard to the admissibility of evidence obtained as result of torture, article 15 of the CAT cannot be clearer. It requires that '[e]ach state party shall ensure that any statement which is established to have been made as a result of torture shall not be invoked as evidence in any proceedings, except against a person accused of torture as evidence that the statement was made. The absolute prohibition on the use of torture in both our law and in international law therefore demands that "any evidence" which is obtained as a result of torture must be excluded 'in any proceedings.'

The above finding by the SCA brings me to the second point that I would like to make about article 15 of the CAT. Article 15 refers to 'any statement'. Jurisprudence and practice from the CAT Committee shows that in cases where the Committee has dealt with article 15 , the evidence in question was either a confession or a statement. ${ }^{1 \xi}$ However, the SCA held above that the absolute prohibition of torture in national and international law means that 'any evidence' obtained as a result of torture must be excluded. There are two important issues to note about this finding. First, the Court, although it refers to article 15 of the CAT, does not hold, and rightly so in my opinion, that it extends beyond statements obtained as a result of torture. The drafting history of article 15 clearly shows that the drafters consciously made a decision to limit it to statements obtained as a result of torture. ${ }^{14}$ Second, in order to ensure that the loophole in article 15 is cured, the SCA invokes, rather ingeniously, the argument that the prohibition on the use of torture is absolute in national and international law and, because of that prohibition, 'any evidence' obtained in violation of the right to freedom from torture 'must be excluded in "any proceedings"'. This same approach has been adopted by the Supreme Court of Zimbabwe in the case of Mukoko $\mathrm{V}$ Attorney-General. ${ }^{15}$ One should recall that the right to freedom from

$11 \mathrm{Eg}$, in its first proposal Sweden had suggested that the Convention should also prohibit the admission of evidence obtained through CIDT. See M Nowak \& $\mathrm{E}$ McArthur The United Nations Convention against Torture: A commentary (2008) 505-507.

12 Mthembu (n 3 above) para 32.

13 See generally Nowak \& McArthur (n 11 above) 512-519.

14 Nowak \& McArthur (n 11 above) 505-507.

15 [2012] JOL 29664 (ZS). In this case, the prosecution intended to use evidence obtained through torture and CIDT in the prosecution of the applicant. In holding that the evidence in question was inadmissible, the Court held, inter alia, that '[i]t is clear that the rationale for the exclusionary rule against the admission or use of information or evidence obtained from an accused person or any third party by infliction of torture, or inhuman or degrading treatment as contained in section 15(1) of the [Lancaster] Constitution, is founded on the absolute obligation imposed on the state. It is also founded on the revulsion which attaches to the 
torture is not only an absolute right, but that the prohibition against torture has acquired the status of jus cogens in international law. ${ }^{16}$ The Court also emphasises the fact that evidence obtained through torture must be excluded in 'any proceedings'. This is broad enough to include, for example, extradition proceedings. The impact of the SCA's ruling in Mthembu means that even a pointing out based on a statement which was obtained as a result of torture is inadmissible. ${ }^{17}$ In $S \vee$ Tandwa \& Others $^{18}$ the SCA, although it did not refer to article 15 of the CAT, quoted with approval a dissenting opinion of one of the judges of the SCA in an earlier decision to hold that ${ }^{19}$

the admission of derivative evidence obtained in circumstances involving some form of compulsion, or as a result of torture, 'however relevant and vital for ascertaining the truth, would be undeniably detrimental to the administration of justice'.

Like the SCA, the Constitutional Court also held: ${ }^{20}$

Where, for example, derivative evidence is obtained as a result of torture there might be compelling reasons of public policy for holding such evidence to be inadmissible even if it can be proved independently of the accused. Otherwise, the ends might be allowed to justify the means. The admission of evidence in such circumstances could easily bring the administration of justice into disrepute and undermine the sanctity of the constitutional right which has been trampled upon.

The above decisions show that any evidence obtained through torture is inadmissible. It does not matter what the kind of evidence is. The CAT Committee's practice, especially with regard to periodic reports submitted by state parties, shows that the Committee has recommended that state parties should ensure that 'any statement' or

source of such information or evidence coupled with its offensiveness to civilised values and its degrading effect on the administration of justice. The rule applies even when the evidence is reliable and necessary to secure the conviction of an accused person facing serious charges. The reliability or probative value of the information or evidence is irrelevant because its admissibility is prohibited in absolute and peremptory terms. It is vital in a society governed by the rule of law that persons in the custody of public officials should not be subjected to illtreatment of the level of severity prohibited by section 15(1) of the [Lancaster] Constitution.' See 36.

16 CAT Committee General Comment 2 (Implementation of article 2 by state parties) CAT/C/GC/2, 24 January 2008, para 1.

17 As was the case in this case.

182008 (1) SACR 613 (SCA).

19 Tandwa (n 18 above) para 19.

20 Ferreira $v$ Levin NO \& Others; Vryenhoek \& Others $v$ Powell NO \& Others 1996 (1) SA 984 (CC); 1996 (1) BCLR 1 para 150. 
statements ${ }^{21}$ or confessions ${ }^{22}$ or 'evidence ${ }^{23}$ obtained as a result of torture should be inadmissible. The UN Special Rapporteur on Torture has also recommended that any evidence obtained as a result of

21 Concluding Observations of the Committee against Torture on the fourth periodic report of Israel, CAT/C/ISR/CO/4, 23 June 2009, para 25; Concluding Observations of the Committee against Torture on the fourth periodic report of Mexico, CAT/C/MEX/CO/4, 6 February 2007, para 22; Concluding Observations of the Committee against Torture on the third periodic report of Armenia, CAT/C/ ARM/CO/3, 6 July 2012, para 16; Concluding Observations of the Committee against Torture on the combined fourth to sixth periodic reports of Paraguay, CAT/C/PRY/CO/4-6, 14 December 2011, para 20; Concluding Observations of the Committee against Torture on the fifth and sixth combined periodic report of Finland, CAT/C/FIN/CO/5-6, 29 June 2011, para 21; Concluding Observations of the Committee against Torture on the initial report of Chad, CAT/C/TCD/CO/1, 4 June 2009, para 29; Concluding observations of the Committee against Torture on the second periodic report of Tajikistan, CAT/C/TJK/CO/2, 21 January 2013, para 13; and Concluding observations of the Committee against Torture on the third periodic report of Senegal, CAT/C/SEN/CO/3, 17 January 2013, para 13.

22 Concluding Observations of the Committee against Torture on the second periodic report of Yemen, CAT/C/YME/CO/2/Rev 1, 25 May 2010, para 28; Concluding Observations of the Committee against Torture on the second periodic report of Jordan, CAT/C/JOR/CO/2, 25 May 2010, para 30; Concluding Observations of the Committee against Torture on the second periodic report of Cambodia, CAT/C/KHM/CO/2, 20 January 2011, para 28; Concluding Observations of the Committee against Torture on the initial periodic report of Djibouti, CAT/C/DII/CO/1, 22 December 2011, para 20; Concluding Observations of the Committee against Torture on the third periodic report of Armenia, CAT/C/ ARM/CO/3, 6 July 2012, para 16; Concluding Observations of the Committee against Torture on the second periodic report of the Philippines, CAT/C/PHL/CO/ 2, 29 May 2009, para 23; Concluding Observations of the Committee against Torture on the initial report of Ethiopia, CAT/C/ETH/CO/1, 20 January 2011, para 31; Concluding Observations of the Committee against Torture on the second periodic report of the Republic of Moldova, CAT/C/MDA/CO/2, 29 March 2010, para 21; Concluding Observations of the Committee against Torture on the fourth periodic report of Belarus, CAT/C/BLR/CO/2, 7 December 2011, para 18; Concluding Observations of the Committee against Torture on the initial report of Mauritania, CAT/C/MRT/CO/1, 18 June 2013, para 8(c); Concluding Observations of the Committee against Torture on the third periodic report of Senegal, CAT/C/ SEN/CO/3, 17 January 2013, para 13; Concluding Observations of the Committee against Torture on the fifth periodic report of the Russian Federation, CAT/C/RUS/ CO/5, 11 December 2012, para 10; and Concluding Observations of the Committee against Torture on the combined fifth and sixth periodic reports of Mexico, CAT/C/MEX/CO/5-6, 11 December 2012, para 15(a).

23 Concluding Observations of the Committee against Torture on the second periodic report of Lithuania, CAT/C/LTU/CO/2, 19 January 2009, para 18; Concluding Observations of the Committee against Torture on the second periodic report of the former Yugoslav Republic of Macedonia, CAT/C/MKD/CO/2, 21 May 2008, para 18 (the Committee also called upon the state party to ensure that any evidence obtained as a result of ill-treatment is inadmissible); Concluding Observations of the Committee against Torture on the third periodic report of Iceland, CAT/C/ISL/CO/3, 8 July 2008, para 13; Concluding Observations of the Committee against Torture on the second periodic report of Cambodia, CAT/C/ $\mathrm{KHM} / \mathrm{CO} / 2$, 20 January 2011, para 28; Concluding Observations of the Committee against Torture on the combined third and fourth periodic report of Sri Lanka, CAT/C/LAK/CO/3-4, 8 December 2011, para 11; Concluding Observations of the Committee against Torture on the initial report of Ethiopia, $\mathrm{CAT} / \mathrm{C} / \mathrm{ETH} / \mathrm{CO} / 1,20$ January 2011, para 31; Concluding Observations of the Committee against Torture on the fifth periodic report of Sweden, CAT/C/SWE/ CO/5, 4 June 2008, para 22; Concluding Observations of the Committee against 
torture be excluded. ${ }^{24}$ The Subcommittee on Prevention of Torture and Other Cruel, Inhuman or Degrading Treatment or Punishment has recommended that statements obtained as a result of torture not be admitted in evidence. ${ }^{25}$ The Human Rights Committee has similarly recommended that evidence obtained through torture be inadmissible. ${ }^{26}$ It is argued that all those situations have different implications in the South African law of evidence. In cases where a state is required to ensure that a statement made as a result of torture is inadmissible, strictly speaking, the obligation in question would require the state to exclude confessions, admissions and extra-curial statements. In the South African law of evidence, these are three different but related kinds of evidence. ${ }^{27}$ In terms of this obligation, real evidence based on an inadmissible statement could be admitted. For example, the statement is excluded but a weapon discovered on the basis of the statement that was made as a result of torture is admissible. This is the practice in countries such as Uganda. Ugandan courts have always excluded confessions or admissions obtained as a result of torture. ${ }^{28}$ However, in Uganda 'evidence obtained through information obtained by torture is admissible and the police have been keen to exploit this loophole'. ${ }^{29}$ In light of the above jurisprudence from the South Africa courts, this interpretation of article 15 of the CAT is not acceptable in South Africa.

Torture on the combined fourth to sixth periodic reports of Paraguay, CAT/C/PRY/ CO/4-6, 14 December 2011, para 20; Concluding Observations of the Committee against Torture on the initial report of Turkmenistan, CAT/C/TKM/CO/1, 15 June 2011, para 20; and Concluding Observations of the Committee against Torture on the fifth periodic report of New Zealand, CAT/C/NZL/CO/5, 4 June 2009, para 15;

24 Report of the Special Rapporteur on Torture and Other Cruel, Inhuman or Degrading Treatment or Punishment, Juan E Mendez, Mission to Tunisia, A/HRC/ 19/61/Add.1, 2 February 2012, para 102(d); and Report of the Special Rapporteur on Torture and Other Cruel, Inhuman or Degrading Treatment or Punishment, Juan E Méndez, Mission to Ghana, A/HRC/25/60/Add.1, 5 March 2014, para IV $(B)(c)$.

25 Report on the visit of the Subcommittee on Prevention of Torture and other Cruel, Inhuman or Degrading Treatment or Punishment to Honduras, CAT/OP/HND/1, 10 February 2010, para 150.

26 Concluding Observations of the Human Rights Committee on the second periodic report of Tajikistan, CCPR/C/TJK/CO/2,22 August 2013, para 14.

27 See, eg, Litako \& Others v S [2014] 3 All SA 138 (SCA). In this case, the Supreme Court of Appeal discusses the differences between confessions, admissions and extra-curial statements. For a discussion of this case, see JD Mujuzi 'The admissibility of an extra-curial admission by an accused as hearsay evidence against a co-accused in South Africa: Litako \& Others $v S$ reconsidering $S v N d h l o v u$ \& Others' (2015) 19 The International Journal of Evidence and Proof 3-10.

28 See the Republic of Uganda Report to the African Commission on Human and Peoples' Rights (May 2006) para 36.1.

29 As above. Sec 14(1) of the Ugandan Prohibition and Prevention of Torture Act 2012, which was assented to by the Ugandan President in July 2012, prohibits the admission of any information, confession or admission obtained from a person as a result of torture. For a detailed discussion of this Act, see JD Mujuzi 'Issues to grapple with in implementing the Ugandan Prohibition and Prevention of Torture

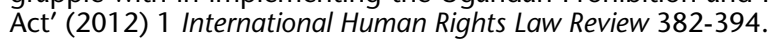


The second issue relates to the CAT Committee's observation that state parties should ensure that confessions made as a result of torture are inadmissible. As mentioned earlier, in the South African law of evidence there is a clear distinction between a confession, on the one hand, and an admission, on the other. This distinction has been emphasised recently by the SCA. ${ }^{30}$ A strict interpretation of this approach would mean that an admission and real evidence or any fact discovered as a result of torture would be admissible. As in the first situation above, jurisprudence from South African courts shows that this would also be untenable in South Africa. The last approach, and one which is supported by jurisprudence from South African courts, is the requirement to exclude any evidence obtained as a result of torture. This would require the exclusion of statements, admissions, confessions, real evidence and any fact discovered as a result of torture. This is a broader and more progressive application of article 15. Admittedly, article 15 is expressly limited to statements, but it would be an affront on the accused's right to a fair trial to admit any evidence obtained as a result of torture. Admitting evidence obtained as a result of torture would also encourage law enforcement officers to use torture easily as a method of interrogation. ${ }^{31}$ The issue of the manner in which the CAT Committee and other UN human rights bodies have dealt with the admissibility of evidence obtained as a result of CIDT is dealt with in the next section.

As at the United Nations (UN) level, at the African regional human rights level South Africa also has an obligation not to admit evidence obtained as a result of torture. As mentioned earlier, article 5 of the African Charter on Human and Peoples' Rights (African Charter) protects the right to freedom from torture. In Egyptian Initiative for Personal Rights and Interights $v$ Egypt $I,{ }^{32}$ the African Commission on Human and Peoples' Rights (African Commission) found that the victim's trial had been unfair because they had been convicted, inter

30 See Litako (n 27 above).

31 In Mukoko (n 15 above), the Supreme Court of Zimbabwe held that ' $[\mathrm{t}] \mathrm{he}$ rationale for the exclusionary rule is the protection of any person suspected of a crime who is in the custody of a public officer from torturous, or inhumane or debasing invasions of his or her dignity and physical integrity. Its object is to ensure that criminal prosecutions which are a direct consequence of the pre-trial illegality violative of fundamental rights of an accused person to freedom from torture, inhuman and degrading treatment are not used to give legitimacy to such conduct. The rule has nothing to do with the fair determination of the guilt or innocence of the accused person. Where there is independent evidence which has been obtained lawfully and on which reasonable suspicion of the accused person having committed the criminal offence with which he or she is charged is founded, an order of permanent stay of a criminal prosecution is not justified. The rule represents a device designed to deter disregard for constitutional prohibitions and give substance to constitutionally-protected fundamental rights. The exclusionary rule as a remedy for the enforcement of the protection of fundamental rights under the Constitution is not intended to immunise an accused person from criminal prosecution for any action he or she is reasonably suspected of having committed which is provable at the trial by independent evidence lawfully obtained.' See 34 . 
alia, on the basis of confessions obtained as a result of torture. The African Commission held, inter alia, that ${ }^{33}$

[i]n interpreting article 7 of the African Charter, the African Commission has stated that 'any confession or other evidence obtained by any form of coercion or force may not be admitted as evidence or considered as probative of any fact at trial or in sentencing'. ... [T] his Commission has held that 'any confession or admission obtained during incommunicado detention shall be considered to have been obtained by coercion'.

The African Commission added that ${ }^{34}$

t]hese principles correspond with other international human rights norms, addressed in relation to torture and ill-treatment, under which evidence and confessions obtained through torture or cruel, inhuman and degrading treatment, cannot be used in judicial proceedings apart from for the purpose of prosecuting the act of torture or ill-treatment itself.

The African Commission further stated that ${ }^{35}$

[o]nce a victim raises doubt as to whether particular evidence has been procured by torture or ill-treatment, the evidence in question should not be admissible, unless the state is able to show that there is no risk of torture or ill-treatment. Moreover, where a confession is obtained in the absence of certain procedural guarantees against such abuse, for example during incommunicado detention, it should not be admitted as evidence.

The African Commission concluded: ${ }^{36}$

The victims in this case all raised allegations of torture and ill-treatment. These allegations are at least consistent with the circumstances of their case, such as the incommunicado nature of their detention and the reports of the FMA which, at a minimum, indicate a risk of ill-treatment. Despite these concerns, the 'confessions' were admitted as evidence and appear to have formed at least part of the basis of their convictions and the imposition of the death penalty. The reliance on such evidence violates article 7 of the Charter.

The question is to what extent the above decision of the African Commission strengthens the position of the exclusion of evidence obtained as a result of torture. Below are some of the observations that one could make about the above finding. One, for a confession or any other evidence to be excluded, it is not a requirement that the victim has been tortured. All that is needed is that coercion or duress was used. This is in line with South African law to the effect that, for a confession to be admissible in evidence, it should have been made freely and voluntarily and without undue influence. ${ }^{37}$ The African Commission also holds that evidence obtained through torture or CIDT cannot be used in judicial proceedings. This reasoning is broader than the stipulation under article 15 of the CAT which, as we have

33 Egyptian Initiative (n 32 above) para 212 (footnotes omitted).

34 Egyptian Initiative para 213.

35 Egyptian Initiative para 218.

36 Egyptian Initiative para 219.

37 See sec 217 of the Criminal Procedure Act. 
seen above, is limited to evidence obtained through torture. This issue will be dealt with in detail below. The third point is that, where a victim alleges that a confession was obtained as a result of torture, coercion or duress, the state has the burden to prove that the confession in question was obtained freely, voluntarily and without undue influence. This is the same position as in South African law. ${ }^{38}$ Finally, the African Commission's finding seems to suggest that for a confession or evidence that was obtained as a result of torture, coercion or duress to be inadmissible, the torture, coercion or duress should have been inflicted or directed against the accused. It is argued that such an interpretation would make room for law enforcement officers to torture third parties for the purpose of acquiring evidence to use against the accused. As indicated earlier, in Mthembu the SCA held that article 15 of the CAT is applicable to evidence that is obtained from the accused and third parties. Like the South African SCA, the Zimbabwean Supreme Court held, in the case of Mukoko $v$ Attorney-General, that evidence or information obtained from the accused or a third party through torture is inadmissible. ${ }^{39}$ The above discussion demonstrates that, at the national, regional and international levels, evidence obtained through torture is inadmissible. Although some South African authors and the Constitutional Court have cautioned against laying down a hard and fast rule on excluding evidence obtained through violating any right in the Bill of Rights, 40 it is submitted that there is no doubt that a rule exists in international law and in South African law that evidence obtained through torture must be excluded. Below our attention shifts to the question of evidence obtained through CIDT.

\section{Evidence obtained through cruel, inhuman or degrading treatment and the case for its absolute exclusion}

It was mentioned earlier that article 15 of the CAT does not require state parties to exclude evidence obtained as a result of CIDT. Leading torture scholars have expressed different views on whether states have an obligation under article 15 to exclude evidence obtained as a result of CIDT. Some have argued that states have such an obligation and others have argued that they do not. ${ }^{41}$ The question that we have to answer is whether South Africa has an obligation in national and international law to exclude evidence obtained as a result of CIDT. It

38 Eg, in S v Mkhize 2011 (1) SACR 554 (KZD) para 33, it was held that '[i]t is a trite principle of our law that the onus is on the state to prove, beyond a reasonable doubt, that the confession was made freely and voluntarily, and without any undue influence, by the accused whilst in his sound and sober senses'.

39 Mukoko (n 15 above) 35.

40 Zeffert \& Paizes (n 8 above) 740.

41 Nowak \& McArthur (n 11 above) 534-536. 
will be argued that South Africa has that obligation. In support of my argument I will rely on South African law and the emerging practice from international human rights bodies or mechanisms. However, before I embark on that discussion, it is critical to say a few things about cruel, inhuman and degrading treatment or punishment.

Unlike torture, CIDT is not defined under the CAT. This is attributable to the drafting history of the Convention. Nowak and McArthur observe that '[d]uring the drafting of article 16 , it ... soon became clear that a proper definition of the term cruel, inhuman or degrading treatment or punishment was impossible to achieve'. ${ }^{42}$ Different approaches have been suggested as the criterion that should be used to distinguish torture from CIDT. Nowak and McArthur argue that $^{43}$

the decisive criterion for distinguishing torture from cruel and inhuman treatment is not the intensity of the pain or suffering inflicted but the purpose of the conduct, the intention of the perpetrator, and the powerlessness of the victim.

They add that ' $[d]$ egrading treatment or punishment can be defined as the infliction of pain or suffering, whether physical or mental, which aims at humiliating the victim' ${ }^{44}$ On the other hand, the CAT Committee has stated that '[i]n comparison to torture, ill-treatment may differ in the severity of pain and suffering and does not require proof of impermissible purposes' ${ }^{45}$ The Committee stated that ${ }^{46}$

[t]he obligation to prevent torture in article 2 is wide-ranging. The obligations to prevent torture and other cruel, inhuman or degrading treatment or punishment (hereinafter 'ill-treatment') under article 16 , paragraph 1, are indivisible, interdependent and interrelated. The obligation to prevent ill-treatment in practice overlaps with and is largely congruent with the obligation to prevent torture. Article 16, identifying the means of prevention of ill-treatment, emphasizes 'in particular' the measures outlined in articles 10 to 13 , but does not limit effective prevention to these articles, as the Committee has explained, for example, with respect to compensation in article 14 . In practice, the definitional threshold between ill-treatment and torture is often not clear. Experience demonstrates that the conditions that give rise to ill-treatment frequently facilitate torture and therefore the measures required to prevent torture must be applied to prevent ill-treatment. Accordingly, the Committee has considered the prohibition of ill-treatment to be likewise non-derogable under the Convention and its prevention to be an effective and nonderogable measure.

In a South African context, it is important to draw a distinction between torture, on the one hand, and CIDT, on the other. This is because of the fact that courts have expressly held that any evidence obtained through torture must be excluded. Of course, the inquiry to

42 Nowak \& McArthur 540

43 Nowak \& McArthur 558 (emphasis in original).

44 As above.

45 CAT Committee General Comment 2 (n 16 above) para 10.

46 CAT Committee General Comment 2 para 3. 
exclude that evidence has to be conducted in light of section 35(5) of the Constitution. It is submitted that there is only one possible outcome of the inquiry under section 35(5) of the Constitution when the court is dealing with evidence obtained through torture: that evidence must be excluded. In other words, once a court finds that torture was used, it has no alternative but to exclude the evidence. In the case of Tandwa, the SCA held that evidence obtained through any form of 'compulsion' is inadmissible. Another meaning for compulsion is force, and force always includes physical power or the threat of physical power. In other words, the person in custody, although not tortured, knows that if he or she does not make a confession or give evidence, he or she will be forced physically to do so. The SCA makes it very clear in Tandwa: ${ }^{47}$

Though 'hard and fast rules' should not be readily propounded, admitting real evidence procured by torture, assault, beatings and other forms of coercion violates the accused's fair trial right at its core, and stains the administration of justice. It renders the accused's trial unfair because it introduces into the process of proof against him evidence obtained by means that violate basic civilised injunctions against assault and compulsion. And it impairs the administration of justice more widely because its admission brings the entire system into disrepute, by associating it with barbarous and unacceptable conduct.

It is critical at this point to also recall the distinction between two kinds of evidence: a confession or an admission and derivative evidence, that is, real evidence or any form of evidence discovered as a result of a confession. As mentioned earlier, in terms of section 217(1) of the Criminal Procedure Act, ${ }^{48}$ for a confession to be valid it has to have been made freely and voluntarily, the confessor must have been in his or her sound and sober senses and he or she must not have been unduly influenced. At common law, an admission must also be made freely and voluntarily for it to be admissible. ${ }^{49}$ Against that background, a confession made as a result of CIDT is inadmissible on the basis of section 217. However, the inquiry does not stop there. Section 218 of the Criminal Procedure Act provides:

(1) Evidence may be admitted at criminal proceedings of any fact otherwise admissible in evidence, notwithstanding that the witness who gives evidence of such fact, discovered such fact, or obtained knowledge of such fact only in consequence of information given by an accused appearing at such proceedings in any confession or statement which by law is not admissible in evidence against such accused at such proceedings, and notwithstanding that the fact was discovered or came to the knowledge of such witness against the wish or will of such accused.

(2) Evidence may be admitted at criminal proceedings that anything was pointed out by an accused appearing at such proceedings or that any fact or thing was discovered in consequence of information given by

$47 \quad$ Tandwa (n 18 above) para 120.

48 Criminal Procedure Act 51 of 1977.

49 See generally Litako (n 27 above). 
such accused, notwithstanding that such pointing out or information forms part of a confession or statement which by law is not admissible in evidence against such accused at such proceedings.

In the case of Matlou \& Another $v$ S, the SCA held: 50

Undoubtedly, there is a direct clash between s 218(2) of the [CPA] and s $35(1)(a) ;(b) ;$ and (c) read with s 35(5) of the Constitution. It is this conflict which we are required to resolve in this appeal. The answer to this somewhat intractable legal conundrum lies in s 35(5) of the Constitution which provides: 'Evidence obtained in a manner that violates any right in the Bill of Rights must be excluded if the admission of that evidence would render the trial unfair or otherwise be detrimental to the administration of justice.'

The above ruling by the SCA shows that the mere fact that a confession has been held inadmissible on the basis that it was obtained in violation of the accused's right does not mean that any fact or pointing out derived from that confession, in itself, is inadmissible. The question that a court would have to answer is whether the admission of the evidence in question would render the trial unfair or otherwise be detrimental to the administration of justice. In the case of torture, the confession and the derivative evidence would have to be inadmissible. However, the position is unclear with regard to a confession obtained as a result of violating the accused's right to freedom from CIDT. The author has not come across any case in which a South African court held that any evidence obtained as a result of violating the accused or a third party's right to freedom from CIDT is inadmissible. This means that, for example, a suspect could be detained under dehumanising conditions to compel him to disclose or point out where he hid the weapon he used in the commission of an offence. Because of the fact that the conditions of his detention cannot be classified as torture, nothing bars a court to invoke section 35(5) to admit the weapon in question as evidence. It should be recalled that the Constitutional Court has expressly held that '[w]hile it is not easy to distinguish between the three concepts "cruel", "inhuman" and "degrading", the impairment of human dignity, in some form and to some degree, must be involved in all three'. ${ }^{51}$ South African courts have given the following as some of the examples of treatment that amounts to cruel, inhuman or degrading treatment: degrading punishments; ${ }^{52}$ excessive punishments; ${ }^{53}$

50 [2010] 4 All SA 244 (SCA) para 22.

51 S V Dodo 2001 (3) SA 382 (CC) para 35.

52 S V Saayman 2008 (1) SACR 393 (E), where the accused was convicted of fraud and the magistrate ordered, inter alia, that she should stand for 15 minutes every day 'in the foyer of the court carrying a placard bearing her name, the fact of her conviction, and an apology to certain of the victims of the frauds'. On appeal it was held that that punishment violated sec 12(1)(e) of the Constitution.

53 In S V Fhetani 2007 (2) SACR 590 (SCA) it was held that a 'grossly disproportionate sentence does not only violate the accused person's right to a fair trial but also his or her right not to be punished in a cruel, inhuman or degrading manner' (para 6); S v Makena 2011 (2) SACR 294 (GNP) para 13, where the court held that 
asking witnesses irrelevant and uncomfortable questions; ${ }^{54}$ the manner in which the deceased was murdered; 55 the setting of police dogs to suspected illegal immigrants; ${ }^{56}$ and corporal punishment. ${ }^{57}$ As mentioned earlier, the purpose of this article is to argue that South African courts should invoke international human rights law practice to treat evidence obtained through CIDT in the same way as evidence obtained through torture. In order to support my argument, I make the points below.

Section 39(1)(b) obliges South African courts to consider international law in interpreting the Bill of Rights. Courts have indeed referred to international law, both binding and non-binding on South Africa, in interpreting the Bill of Rights. ${ }^{58}$ The starting point is therefore the position of international law on the question of the admissibility of evidence obtained as a result of CIDT. The 1975 UN Declaration on the Protection of All Persons from Being Subjected to Torture and Other Cruel, Inhuman or Degrading Treatment or Punishment ${ }^{59}$ provides under article 12 that

[a]ny statement which is established to have been made as a result of torture or other cruel, inhuman or degrading treatment may not be invoked as evidence against the person concerned or against any other person in any proceedings.

'[w] hat has been said about rehabilitation and reformation applies to the period of the appellant's rehabilitation, viewed from the appropriateness or otherwise of the imprisonment for 50 years. It is my considered view, based on the sentences emanating from the Supreme Court of Appeal, that effective sentences exceeding 25 years' imprisonment are not confirmed lightly. Again, the basis for this may be the emphasis on reformation and rehabilitation, based, inter alia, on the constitutional precept that punishment should not be cruel or be deemed to be such. This statement is made with the full knowledge and appreciation of the gravity and devastating effects that the loss of the victim's life has inevitably inflicted on his family, society and the country.' See also S V Nkosi \& Others 2003 (1) SACR 91 (SCA) para 9; S v Niemand 2001 (2) SACR 654 (CC).

54 S v Mbhele 2008 (1) SACR $123(\mathrm{~N})$ para 6.

55 S V Vermeulen 2004 (2) SACR 174 (SCA) para 33, where the court held that '[b]efore the deceased died he was not only physically assaulted but also emotionally traumatised. While he lay injured, the appellant and his brother carried on a discussion about first killing him and then burying him under the carcass of a cow. He was then moved to the cornfield. Once there, some discussion took place to the effect that he should not be shot because that would attract attention. A grave was dug for him while he was still alive. Ultimately, he was struck with a pick axe and buried in the most undignified way possible - for doing no more than collecting firewood. In my view, the aggravating circumstances of this case far outweigh all the other factors, when balanced against one another. The killing was cruel, inhuman and degrading and no selfrespecting society can tolerate deeds of this nature.'

56 S v Smith 2003 (2) SACR 135 (SCA) para 11.

57 See eg Christian Education South Africa v Minister of Education 2000 (4) SA 757 (CC).

58 See, generally, E de Wet 'The "friendly but cautious" reception of international law in the jurisprudence of the South African Constitutional Court: Some critical remarks' (2004-2005) 28 Fordham International Law Journal 1529-1565.

59 GA Res 3452(XXX) of 9 December 1975. 
Practice from international human rights mechanisms also appears to be moving towards the exclusion of evidence obtained through CIDT. While commenting on Austria's periodic report, the Human Rights Committee, the body overseeing the implementation of the International Covenant on Civil and Political Rights (ICCPR), welcomed 'the introduction of an express prohibition of evidence obtained by means of torture or cruel, inhuman, or degrading treatment, or other unlawful interrogation methods' ${ }^{60}$ The Human Rights Committee also recommended that the United States should 'refrain from relying on evidence obtained by treatment incompatible with article $7^{\prime}$ of the ICCPR. ${ }^{61}$ Article 7 of the ICCPR provides that '[n]o one shall be subjected to torture or to cruel, inhuman or degrading treatment or punishment'. This clearly means that the Human Rights Committee has made it very clear that evidence obtained through CIDT should be inadmissible. It is argued that this evidence is not limited to confessions but to all evidence. Like the Human Rights Committee, the CAT Committee welcomed legislative steps in Austria on 'the prohibition of evidence obtained by means of torture or cruel, inhuman, or degrading treatment, or other unlawful interrogation methods'.62 ${ }^{2}$ The CAT Committee has called on Gabon to 'amend its legislation in order to make it clear that confessions, statements and other evidence obtained through torture or illtreatment may not be invoked as evidence in legal proceedings' ${ }^{\prime 63}$ The Committee made a similar recommendation to Rwanda. ${ }^{64}$ The UN Special Rapporteur on the Promotion and Protection of Human Rights and Fundamental Freedoms while Countering Terrorism urged the United States of America to ensure that 'evidence obtained by any form of torture or cruel, inhuman or degrading treatment [is not] admitted in [any] proceedings'.65 The UN Special Rapporteur on the Independence of Judges and Lawyers urged the government of Tajikistan to prioritise the fact that ${ }^{66}$

60 Concluding Observations of the Human Rights Committee on Austria's fourth periodic report, CCPR/C/AUT/CO/4, 30 October 2007 para 5(a).

61 Concluding Observations of the Human Rights Committee on the second and third periodic reports of the United States of America, CCPR/C/USA/CO/3/Rev 1 , 18 December 2006, para 14.

62 Concluding Observations of the Committee against Torture on the fourth and fifth combined periodic reports of Austria, CAT/C/AUT/CO/4-5, 20 May 2010, para 5(a)(i).

63 Concluding Observations of the Committee against Torture on the initial report of Gabon, CAT/C/GAB/CO/1, 17 January 2013, para 24.

64 Concluding Observations of the Committee against Torture on the initial report of Rwanda, CAT/C/RWA/CO/ 1, 26 June 2012, para 23.

65 Report of the Special Rapporteur on the Promotion and Protection of Human Rights and Fundamental Freedoms while Countering Terrorism, Martin Scheinin, Mission to the United States of America, A/HRC/6/17/Add.3, 22 November 2007, para 60.

66 Report of the Special Rapporteur on the Independence of Judges and Lawyers, Leandro Despouy, Mission to Tajikistan, E/CN.4/2006/52/Add.4, 30 December 2005, para 91. 
[a]dequate legal amendments should be introduced to ensure that confessions and other evidence obtained through torture or cruel, inhuman or degrading treatment or duress should under no circumstances be admissible in trials.

As mentioned earlier, the African Commission expressly held in Egyptian Initiative for Personal Rights and Interights $v$ Arab Republic of Egypt ${ }^{67}$ that evidence obtained through CIDT was inadmissible. It is argued that, from an international human rights perspective, there is merit in the argument that South African courts should expressly hold that any evidence obtained as a result of CIDT is inadmissible. There are numerous decisions in which the European Court of Human Rights has found that evidence obtained through torture or duress is inadmissible. ${ }^{68}$ In Jallow $v$ German, ${ }^{69}$ the Court, although it left open the 'the general question whether the use of evidence obtained by an act qualified as inhuman and degrading treatment automatically renders a trial unfair ${ }^{70}$ it added that ${ }^{71}$

[i]t cannot be excluded that on the facts of a particular case the use of evidence obtained by intentional acts of ill-treatment not amounting to torture will render the trial against the victim unfair irrespective of the seriousness of the offence allegedly committed, the weight attached to the evidence and the opportunities which the victim had to challenge its admission and use at his trial.

The Court concluded that it 'finds that the use in evidence of the drugs obtained by the forcible administration of emetics to the applicant rendered his trial as a whole unfair' ${ }^{72}$ because it had, inter alia, been obtained in violation of the applicant's right to freedom from inhuman and degrading treatment contrary to article 3 of the Convention. ${ }^{73}$ Therefore, there is evidence that there are cases where the European Court of Human Rights would find evidence obtained through CIDT inadmissible. However, because of the fact that the Court leaves open the question of whether such evidence should be excluded, this leaves room to some courts to admit such evidence. It is argued that the best approach is that adopted by the African Commission and the practice of the UN human rights bodies above that such evidence should be excluded.

The second point to be made is that, like the right to freedom from torture, the right to freedom from CIDT is also an absolute and non-

67 Egyptian Initiative (n 32 above).

68 See, eg, Baran and Hun v Turkey Application 30685/05 (20 May 2010) para 72. See also Desde v Turkey Application 23909/03 (1 February 2011); Fidanci v Turkey Application 17730/07 (17 January 2012); Özcan Çolak $v$ Turkey Application 30235/03 (6 October 2009) para 49; Harutyunyan v Armenia Application 36549/ 03 (28 June 2007).

69 Jallow $v$ German Application 54810/00 (11 July 2006).

70 Jallow $v$ German (n 69 above) para 107.

71 Jallow $v$ German para 106.

72 Jallow $v$ German para 108.

73 Jallow $v$ German para 82. See also Ümit Gül $v$ Turkey Application 7880/02 (26 September 2009). 
derogable right under the South African Constitution and in international law. ${ }^{74}$ As mentioned earlier, in Mthembu, the SCA held that $^{75}$

[t]he absolute prohibition on the use of torture in both our law and in international law therefore demands that 'any evidence' which is obtained as a result of torture must be excluded 'in any proceedings'.

The CAT Committee emphasised that, like the obligation to prevent torture, the obligation to prevent CIDT is also non-derogable. ${ }^{76}$ This means, inter alia, that if courts admit evidence which has been obtained through CIDT, they indirectly cast doubt on the absolute and non-derogable nature of the right to freedom from CIDT. South African courts have held that some forms of punishment amount to CIDT and are therefore unconstitutional. ${ }^{77}$ If a form of punishment that amounts to CIDT is unconstitutional and, therefore, courts are absolutely prohibited from imposing it, one would expect the courts to follow the same logic when it comes to evidence obtained through CIDT. This should be understood against the background that admitting evidence obtained through CIDT could lead to encouraging law enforcement officers to engage in such acts with the inherent danger that they could cross the boundary and end up torturing their victims. As mentioned earlier, the CAT Committee stated: ${ }^{78}$

In practice, the definitional threshold between ill-treatment and torture is often not clear. Experience demonstrates that the conditions that give rise to ill-treatment frequently facilitate torture and therefore the measures required to prevent torture must be applied to prevent ill-treatment.

One of the measures required to prevent torture is the inadmissibility of any evidence obtained as a result of torture. The exclusion of any evidence obtained through CIDT would ultimately strongly contribute to the fight of torture.

It should also be noted that article 16(1) of the CAT provides:

Each state party shall undertake to prevent in any territory under its jurisdiction other acts of cruel, inhuman or degrading treatment or punishment which do not amount to torture as defined in article I, when such acts are committed by or at the instigation of or with the consent or acquiescence of a public official or other person acting in an official capacity. In particular, the obligations contained in articles 10, 11, 12 and 13 shall apply with the substitution for references to torture of references to other forms of cruel, inhuman or degrading treatment or punishment.

74 Art 4 ICCPR

75 Mthembu (n 3 above) para 32.

76 CAT Committee General Comment 2 (n 16 above) para 6.

77 This has been the case with respect to the death penalty, life imprisonment without the possibility of release and corporal punishment. See, generally, JD Mujuzi 'Punishment in the eyes of the Constitutional Court of South Africa: The relationship between punishment and the rights of an offender in the sentencing of primary caregivers of children' (2011) 24 South African Journal of Criminal Justice 164-177.

78 CAT Committee General Comment 2 (n 16 above) para 3. 
Admitting evidence obtained through CIDT would be contrary to South Africa's obligation under article 16(1) of the CAT. Furthermore, if a person has been treated in a cruel, inhuman or degrading way for the purpose of obtaining evidence from him or her, such evidence should be inadmissible because, as the SCA held in Mthembu: $:{ }^{79}$

Public policy ... sets itself firmly against admitting evidence obtained in deliberate or flagrant violation of the Constitution. If, on the other hand, the conduct of the police is reasonable and justifiable, the evidence is less likely to be excluded - even if obtained through an infringement of the Constitution.

It is difficult, if not impossible, to think of a situation where a violation of the right to freedom from CIDT for the purpose of obtaining evidence would be reasonable and justifiable. It should be remembered that the SCA does not state that the conduct has to be reasonable or justifiable. The conduct in question must be reasonable and justifiable for the possibility to admit evidence obtained in violation of the Constitution to arise.

Section $39(1)(c)$ of the Constitution provides that '[w]hen interpreting the Bill of Rights a court, tribunal or forum ... may consider foreign law'. South African courts have indeed considered foreign law in interpreting the Bill of Rights. ${ }^{80}$ It is against this background that it is submitted that South African courts may find jurisprudence emanating from other countries, especially African countries, on the legal status of evidence obtained through CIDT persuasive. ${ }^{81}$ Jurisprudence emanating from some African countries is to the effect that evidence obtained through CIDT should be treated

79 Mthembu (n 3 above) para 26.

$80 \mathrm{Eg}$, in Florence $v$ Government of the Republic of South Africa 2014 (6) SA 456 (CC); 2014 (10) BCLR 1137 (CC) para 52, the Constitutional Court held that '[i]t is helpful to consider foreign law when dealing with a right recognised in the Bill of Rights'.

81 However, the South African Constitutional Court referred to sec 39(1)(c) and held that ' $[\mathrm{f}]$ ) jurisdictions have dealt with the issues that confront us in this matter. At the same time, it is important to appreciate that foreign case law will not always provide a safe guide for the interpretation of our Constitution. When developing our jurisprudence in matters that involve constitutional rights ... we must exercise particular caution in referring to foreign jurisprudence.' See President of the Republic of South Africa \& Others v M \& G Media Ltd 2012 (2) BCLR 181 (CC); 2012 (2) SA 50 (CC) para 16. In Hv Fetal Assessment Centre 2015 (2) BCLR 127 (CC); 2015 (2) SA 193 (CC) para 31, the Court held that '[f]oreign law has been used by this Court both in the interpretation of legislation and in the development of the common law. Without attempting to be comprehensive, its use may be summarised thus: (a) Foreign law is a useful aid in approaching constitutional problems in South African jurisprudence. South African courts may, but are under no obligation to, have regard to it. (b) In having regard to foreign law, courts must be cognisant both of the historical context out of which our Constitution was born and our present social, political and economic context. (c) The similarities and differences between the constitutional dispensation in other jurisdictions and our Constitution must be evaluated. Jurisprudence from countries not under a system of constitutional supremacy and jurisdictions with very different constitutions will not be as valuable as the jurisprudence of countries 
as evidence obtained through torture and must be excluded. For example, section 15(1) of the Lancaster Constitution of Zimbabwe provided that ' $[\mathrm{n}] \mathrm{o}$ person shall be subjected to torture or to inhuman or degrading punishment or other such treatment'. The same prohibition has been enshrined in article 53 of the 2013 Constitution of Zimbabwe. ${ }^{82}$ However, unlike the Lancaster Constitution, the 2013 Constitution includes a provision which regulates the admissibility of evidence obtained through human rights violations. ${ }^{83}$ In Mukoko, ${ }^{84}$ which was decided on the basis of the Lancaster Constitution, the Supreme Court of Zimbabwe, in granting the applicant's application for a permanent stay of prosecution on the ground that the evidence that was to be adduced at her trial had been obtained through torture and CIDT, referred to jurisprudence from different jurisdictions, including South Africa, and to article 15 of the CAT and held, inter alia: 85

The obligation on the state, through its agents, not to admit or use in criminal proceedings, information or evidence obtained from an accused person or any third party by infliction of torture, inhuman or degrading treatment is not explicitly set out by a separate provision in the Constitution. It would be contrary to the object and purpose of the prohibition under section 15(1) of the Constitution to allow admission or use of such information or evidence in any legal proceedings. A proper interpretation of section 15(1) of the Constitution which takes into account the purpose and broadness of the language underlying the importance of the fundamental value protected, compels the Court to conclude that the obligation on the state not to admit or use information or evidence obtained from an accused person or any third party by infliction of torture, or inhuman or degrading treatment in any legal proceedings attaches to the prohibition of such treatment by section 15(1) of the Constitution. The obligation is inherent in the general terms of the section. It enjoys with the general prohibition the same qualities of being absolute and nonderogable. The condemnation is more aptly categorised as a constitutional principle than as a rule of evidence.

founded on a system of constitutional supremacy and with a constitution similar to ours. (d) Any doctrines, precedents and arguments in the foreign jurisprudence must be viewed through the prism of the Bill of Rights and our constitutional values.'

82 Art 53 of the 2013 Constitution of Zimbabwe provides that '[n]o person may be subjected to physical or psychological torture or to cruel, inhuman or degrading treatment or punishment'.

83 See sec 70(3) which provides that '[i]n any criminal trial, evidence that has been obtained in a manner that violates any provision of this chapter must be excluded if the admission of the evidence would render the trial unfair or would otherwise be detrimental to the administration of justice or the public interest'.

84 Mukoko (n 15 above).

85 Mukoko 32-33. 
Although courts in other African countries, such as Lesotho, ${ }^{86}$ Swaziland, ${ }^{87}$ Namibia, 88 Tanzania, ${ }^{89}$ Malawi, ${ }^{90}$ Zambia $^{91}$ and Kenya, ${ }^{92}$ have held that evidence obtained through torture is inadmissible, the author is not aware of any other court, apart from the Zimbabwean Supreme Court, which has held that evidence obtained through CIDT should be treated as evidence obtained through torture. It is submitted that if South Africa follows the international trend and also the example of the Supreme Court of Zimbabwe, the protection of human rights, and in particular the right to a fair trial, will be strengthened.

Section 39(2) of the South African Constitution provides that '[w]hen interpreting any legislation, and when developing the common law or customary law, every court, tribunal or forum must promote the spirit, purport and objects of the Bill of Rights'. In Mthembu the SCA held: ${ }^{93}$

In the pre-constitutional era, applying the law of evidence as applied by the English courts, the courts generally admitted all evidence, irrespective of how obtained, if relevant. The only qualification was that 'the judge always (had) a discretion to disallow evidence if the strict rules of admissibility would operate unfairly against an accused'.

The SCA refers to case law to support its view that, even before the constitutional era, some judges held that evidence which had been obtained from the accused involuntarily had to be excluded. ${ }^{94}$ South African courts have invoked section 39(2) of the Constitution to develop common law which deals with, inter alia, the right to a fair trial. This has been the case, for example, with regard to the offender's right to be heard before a court imposes a sentence on him or her and the offender's right to be heard before an appeal court increases his or her sentence. ${ }^{95}$ It is submitted that nothing prevents courts from developing common law by holding that evidence obtained through CIDT is inadmissible. It should be remembered that in developing common law, courts should always remember South Africa's international obligations. As the Constitutional Court held in Government of the Republic of Zimbabwe $v$ Fick and Others, ${ }^{96}$ '[w] wen courts are required to develop the common law ... they must

$86 R v$ Mpobane (CRI/T/1/94) [1999] LSCA 26 (25 March 1999).

$87 R$ v Dladla \& Others (168/1998) [1998] SZHC 2 (1 January 1998).

88 S v Malumo (CC 32/2001) [2010] NAHC 20 (1 March 2010).

89 Mkika $v$ Republic (Criminal Appeal 47 of 2001) [2003] TZCA 2 (1 August 2003).

90 Palitu \& Others $v$ Republic [2001] MWHC 43 (19 September 2001).

91 People $v$ B (1980) ZR 219 (HC) 234.

92 See JD Mujuzi 'The Constitution in practice: An appraisal of the Kenyan case law on the right to a fair trial' (2008) 2 Malawi Law Journal 135-157.

93 Mthembu (n 3 above) para 22.

94 Mthembu para 23.

95 See JD Mujuzi 'Developing common law to expand the meaning of the right to a fair trial in South Africa: The accused's right to be heard before the court imposes the sentence' (2013) 42 Common Law World Review 137-150.

962013 (5) SA 325 (CC); 2013 (10) BCLR 1103 (CC). 
remember that their "obligation to consider international law when interpreting the Bill of Rights is of pivotal importance"'.97

\section{Conclusion}

Section 35(5) of the South African Constitution empowers a court to admit evidence obtained in a manner that violates any right in the Bill of Rights, provided that the admission of the evidence would not render the trial unfair or otherwise be detrimental to the administration of justice. South African courts have over time developed rich jurisprudence on section 35(5). ${ }^{98}$ Courts have held that any evidence obtained through torture is inadmissible. This is because of the absolute prohibition on torture and the fact that the admission of such evidence would always render the trial unfair and be detrimental to the administration of justice. Courts have not come out to expressly hold that evidence obtained through CIDT is, like the evidence obtained through torture, inadmissible and should be excluded under all circumstances. Relying on the practice of international human rights mechanisms, such as the CAT Committee, the Human Rights Committee, the UN Special Rapporteur on Torture, the UN Special Rapporteur on the Independence of Judges and Lawyers and the African Commission, the author has argued that South Africa has an international obligation to exclude evidence obtained through CIDT. The author has also relied on the jurisprudence of the SCA to argue that there is room for a strong case to be made for the exclusion, under all circumstances, of any evidence obtained through CIDT. The author has also demonstrated that the Supreme Court of Zimbabwe held that evidence obtained through CIDT should be treated as evidence obtained through torture and should be excluded.

97 Government of the Republic of Zimbabwe v Fick \& Others (n 96 above) para 66.

98 Zeffert el at (n 8 above) 711-775. 